\title{
Estimating the benefits of improved drainage on pavement performance
}

\author{
Prashant Kumar Azad ${ }^{1}$, Yogesh U. Shah ${ }^{2}$, S.S. Jain ${ }^{1}$, M. Parida ${ }^{1}$ \\ ${ }^{1 *}$ Department of Civil Engineering, Indian Institute of Technology Roorkee, INDIA \\ ${ }^{2}$ Centre for Transportation Systems, Indian Institute of Technology Roorkee, INDIA \\ *Corresponding Author: e-mail: yogeshfrombaroda@yahoo.co.in, Tel +91-9412023974.
}

\begin{abstract}
The drainage quality is an important parameter which affects the performance of highway pavements. In India, since last few years considerable importance has been given to the drainage as per of pavement. A poor quality of drainage results in premature deterioration of the pavement structure and necessitating large amount of costly repairs or replacement, before they reach their design life. This study presents investigations for premature deterioration of a stretch on National Highway (NH 58) between Rishikesh ( $\mathrm{km} \mathrm{231)}$ and Shivpuri $(\mathrm{km} \mathrm{242)}$ due to poor sub-surface drainage. The sections at $\mathrm{km} 233.800$ and $\mathrm{km}$ 235.900 were identified for this study. Investigations were carried out by field measurements and laboratory tests on samples of permeable base (water bound macadam - WBM) and sub-base (granular sub-base - GSB) layer materials. Laboratory investigations included determination of gradation, optimum moisture content, maximum dry density, and permeability. Three samples were prepared for each test for both WBM and GSB material and average results were used. The pavement sections were evaluated structurally by deflection measurements and functionally by measuring the road roughness. In this study, the benefits of providing good drainage over the service life of the pavement were quantified in terms of vehicle operating cost (VOC). Performances in terms of deflection and roughness were predicted for do-nothing and after applying required maintenance. Vehicle operating costs were computed based on the maintenance strategy for good and poor drainage pavement sections and benefits due to maintenance strategy were estimated. Afterwards, economic benefits of good drainage and poor drainage for identified pavement section were compared.
\end{abstract}

Keywords: Pavement sub-surface drainage, Pavement performance, Vehicle operating cost.

DOI: http://dx.doi.org/10.4314/ijest.v5i3.7

\section{Introduction}

Excessive water content in the pavement base, sub-base and sub-grade soil can cause early distress and lead to a structural or functional failure of pavement. In spite of this, adequate priority for drainage system has not been given either in the planning, organization, fund allocation or monitoring stages of highway development. It is essential to give due priority to this area of development and satisfactory arrangements ensured by way of proper design and planning. Provision of fully permeable pavements can be an alternative to prevent pavement damage due to poor drainage. Fully permeable pavements are those in which all layers are intended to be permeable and the pavement structure serves as a reservoir to store water during storm periods to minimize the adverse effects of storm water runoff. Fully permeable pavements are currently used primarily for light traffic (e.g., parking lots that only allow cars, not trucks). Li et al. (2012) and Li et al. (2013) give the mechanistic-empirical design procedures and the use of fully permeable pavement under heavy traffic has been discussed.

In the present study, section of National Highway (NH 58) was analyzed for the premature deterioration observed on this stretch. The overlay between the stretch km 231.000 (Rishikesh) and km 242.000 (Shivpuri) was done in the year 2011 and was designed for 5 years. These chainage are w.r.to New Delhi, National Capital of India. After 2 years the pavement section was found undergoing deformation, with development of cracks, potholes and rutting. Field tests such as Benkelman Beam Deflection (BBD), roughness study, and materials testing were conducted, to determine the causes of the problems. The investigations 
revealed that the primary cause of pre-mature pavement failure was attributable to poor sub-surface drainage. High proportion of fines in the portion of GSB (granular sub-base) towards the pavement edge and shoulders had resulted in GSB layer to be totally ineffective as a drainage layer. Also the permeability of GSB and base layer was evaluated to conclude about drainage quality of these layers. Economic benefits of good drainage over poor drainage for identified sections were analyzed by determining VOC.

Looking to the problem defined above following objectives were taken for this study: (i) to identify the section of a National Highway with good and poor drainage condition on the basis of laboratory investigation; (ii) to study the effect of drainage on pavement performance and maintenance needs; and (iii) to quantify the benefits in terms of cost due to the improved drainage condition.

\section{Literature Review}

Water-related damage can cause one or more of the following forms of deteriorations: a) Reduction of sub-grade and base/subbase strength, b) Differential swelling in expensive sub-grade soil, c) Stripping of asphalt in flexible pavements, d) Frost heave and reduction of strength during frost melt, and e) Movement of fine particles into base or sub-base course materials resulting in a reduction of the hydraulic conductivity considerably (Jain et al., 1992). Effective surface water drainage of highway pavement is essential for maintaining a desirable level of service and traffic safety. Poor surface drainage contributes to accidents resulted from hydroplaning and loss of visibility from splash and spray. The techniques like controlling the pavement geometry, the use of textured surfaces to include the porous asphalt surface and grooved surfaces, and the more effective use of drainage appurtenances were suggested for reducing the water film thickness (Anderson et al., 1998). In addition to surface drainage, pavement must be designed to allow adequate subsurface drainage. Long-term accumulation of water inside the pavement reduces strength of unbounded granular materials and sub-grade soils, and causes pumping of fine materials with subsequent pavement rapid deterioration. The detrimental effects can be reduced by preventing water from entering the pavement providing adequate drainage to remove infiltration or building the pavement strong enough to resist the combined effect of load and water. Pavement service life can be increased by $50 \%$ if infiltration water can be drained without delay (Rokade et al., 2012). Therefore, pavement drainage design should be at the forefront of pavement design and not an afterthought. It is also noticeable that funds required for a drainage system are small as compared to the development of infrastructure and the recurring losses which the society and the government have to suffer from year to year (IRC: SP 50, 1999).

\section{Identification of Study Sections}

The stretch of NH-58 between Rishikesh and Mana is very important from tourism point of view and due to Char- Dham Yatra in Uttarakhand. During the Yatra season many pilgrims from abroad use to visit the Char-Dham and use to ply on this road. It was observed that the performance of the certain section of stretch between Rishikesh (km231) and Shivpuri (km242) of NH-58 was deteriorating faster than the other section of the same stretch. Specifically two locations near chainage $\mathrm{km} 235.90$ and $\mathrm{km} 233.80$ were identified for the study. The sections of $200 \mathrm{~m}$ each at chainage $\mathrm{km} 235.90$ and $\mathrm{km} 233.80$ were selected for study as shown in Figure. 1. The detailed cross section of the selected stretches of NH-58 is as shown in Figure 2.

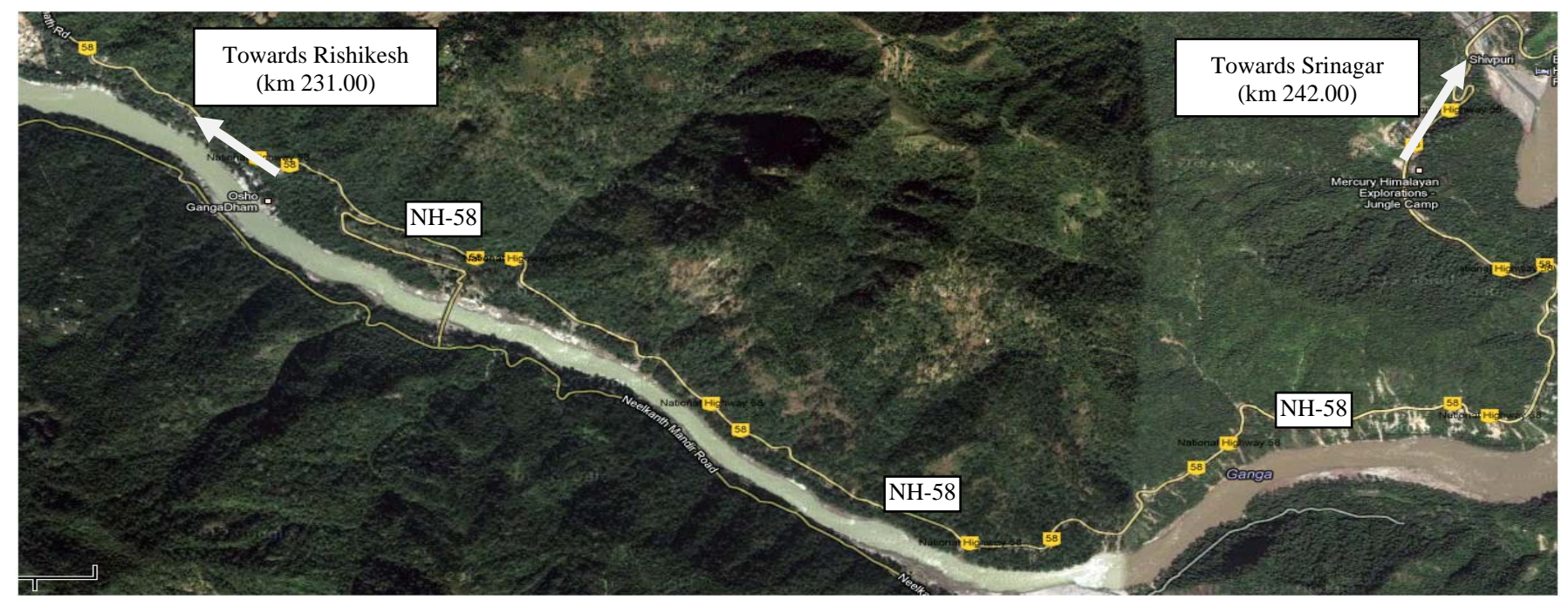

Figure 1: Map Showing Study Area

(Figure not to scale) 


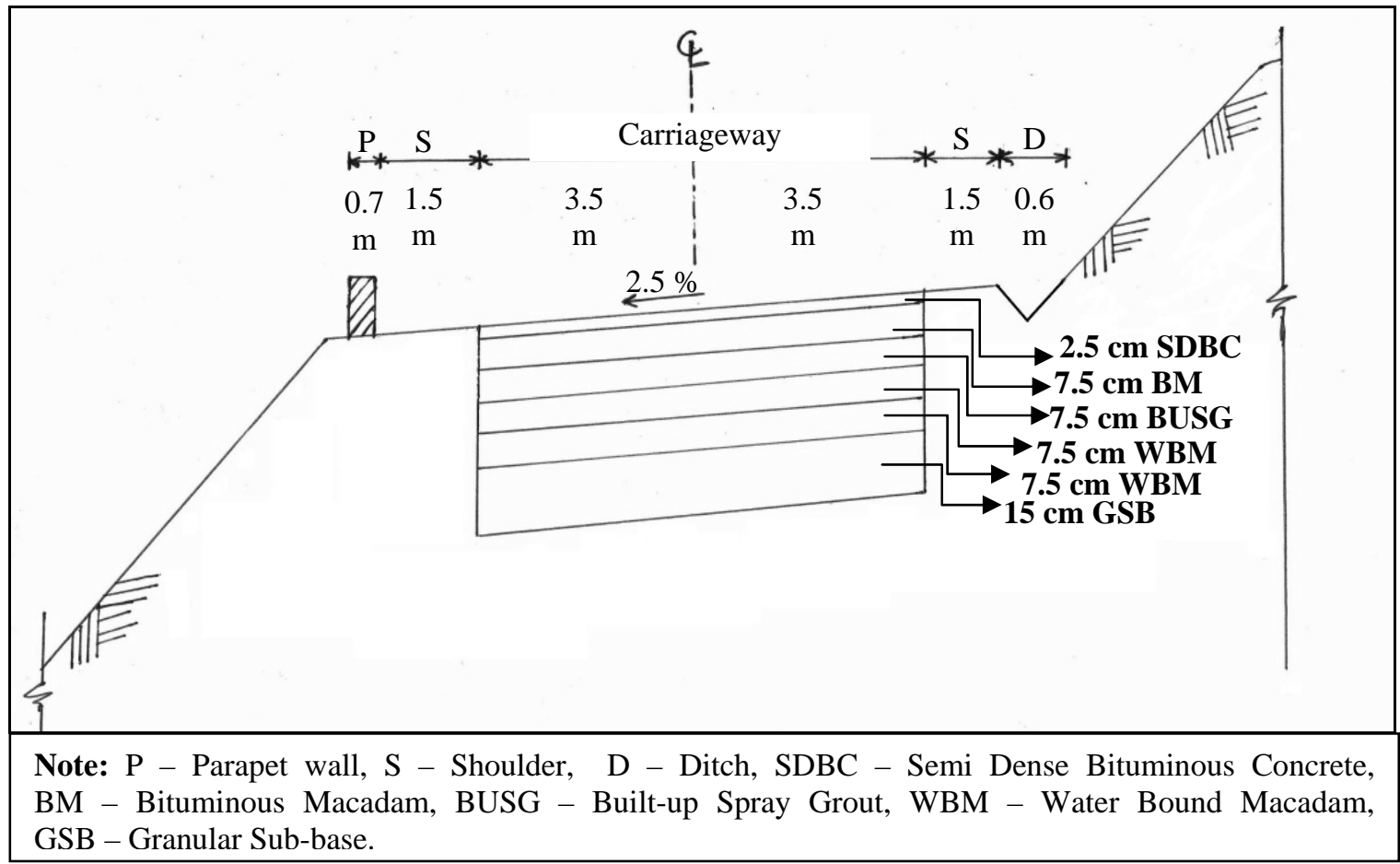

Figure 2: Typical Cross Section of Selected NH - 58 Sections

\section{Data Collection}

Following laboratory and field studies were under taken to study the effect of drainage on pavement performance. Photographs showing various field data collection, sample collection and laboratory testing are given in Fig 3 (a to h).

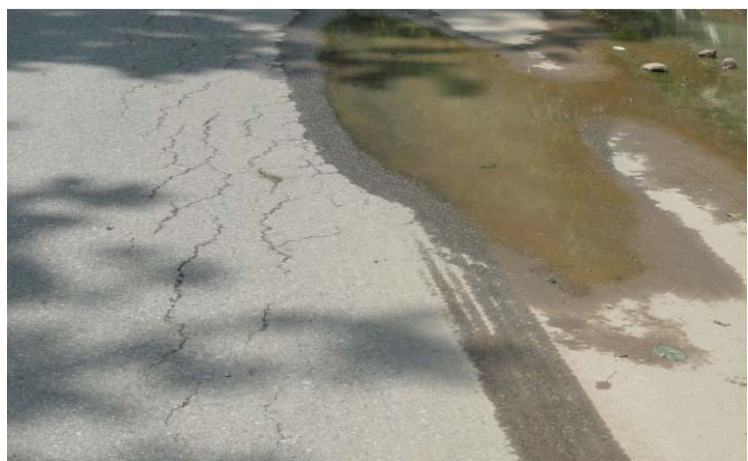

(a) Water Logging Near Chainage km 233.800

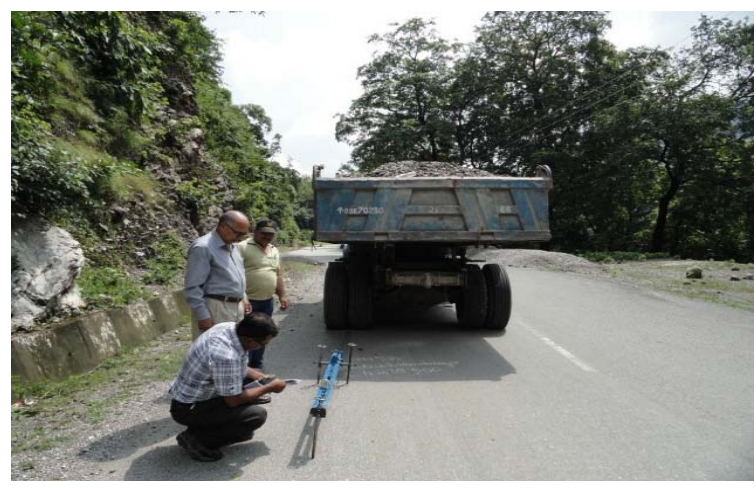

(c) Measurement of Deflection using Benkelman Beam

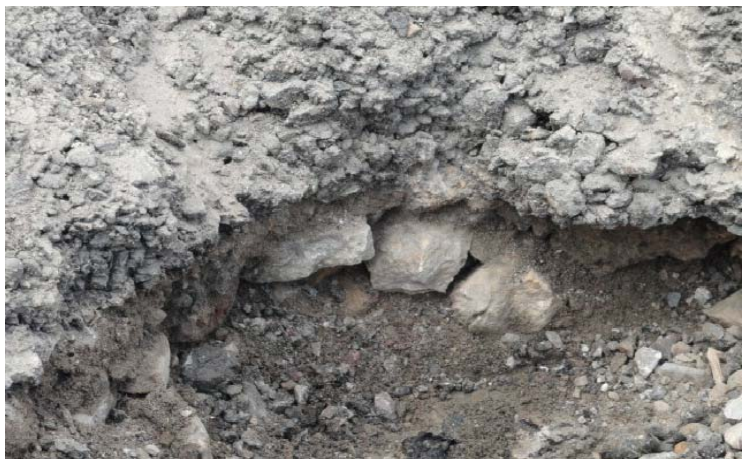

(b) WBM \& GSB Sample Collection

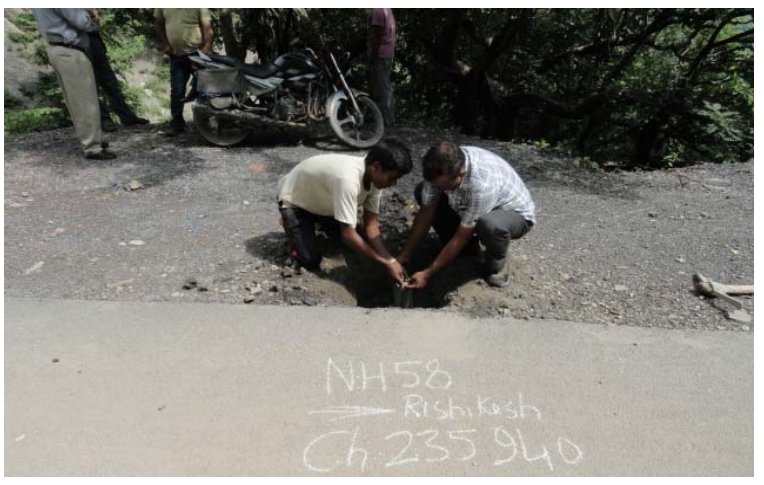

(d) Test Pit to Determine Pavement Layer Thickness 


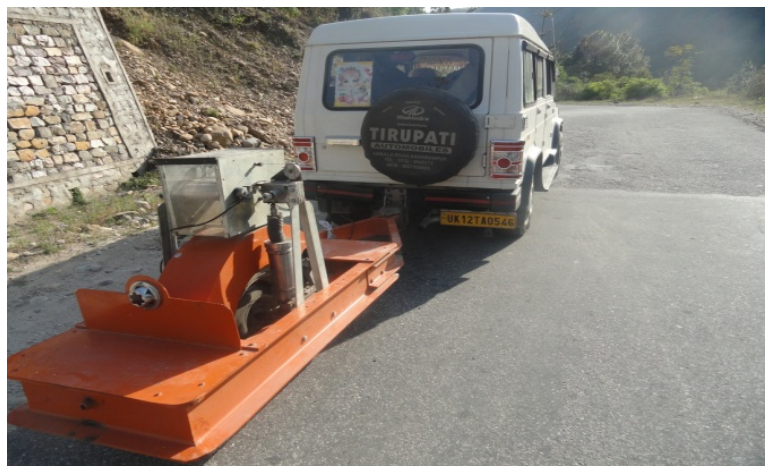

(e) Measurement of Roughness using Bump Integrator

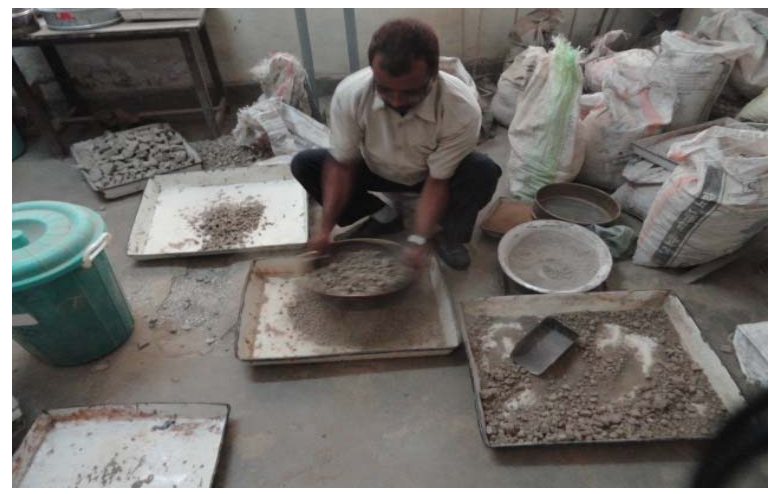

(g) Gradation of GSB Material

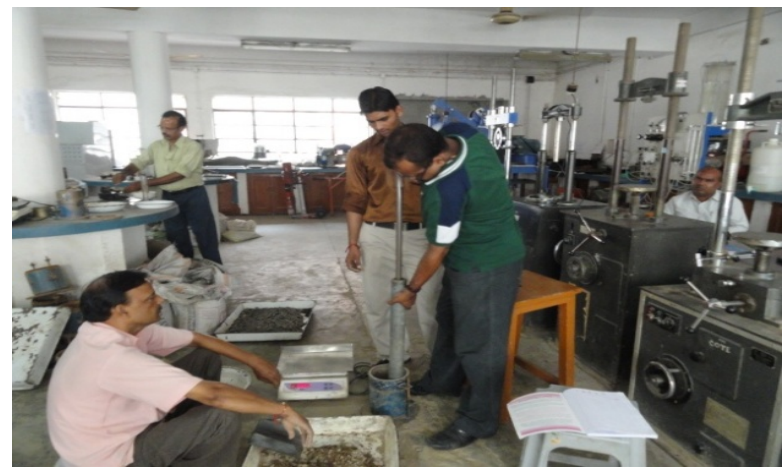

(f) Determination of OMC \& MDD for WBM

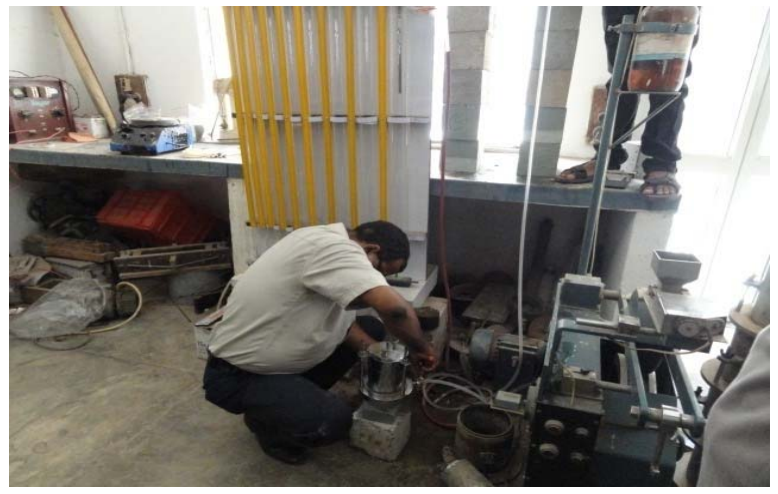

(h) Permeability Test by Constant Head Method

Figure 3: Field Survey and Laboratory Investigations

\subsection{Laboratory Studies}

WBM (water bound macadam) \& GSB (granular sub-base) are two layers which contribute to the drainage for selected pavement sections of NH-58. Samples of WBM \& GSB layer material were collected from both the stretches under observation to analyse the gradation, OMC (optimum moisture content) \& MDD (maximum dry density), and permeability. Samples were collected by digging a test pits as both the locations and were packed in airtight plastic bags to maintain the moisture while transporting them to laboratory. Constant head permeability test was adopted to determine the permeability of the collected samples. Three samples for each test were prepared for both WBM and GSB materials and the results were averaged. Results of the gradation, OMC \& MDD, and permeability of the GSB \& WBM layers are given in Tables 1 to 8. Gradation of WBM \& GSB samples were done to check whether proportion of material passing certain sieve size is within specified limits of MoRT\&H. Particle size distribution, or gradation, of an aggregate is an important aggregate characteristic in determining performance of pavement. Permeability, moisture susceptibility, stability, stiffness, durability are some of the important properties which are governed by aggregate gradation. Ggradation of screenings is to check that percentage of fines present in the mix is not too high to prevent the drainage ability of the layer.

Table 1. Gradation of GSB Component Layer Material (km 235.900)

\begin{tabular}{|c|c|c|}
\hline Sieve size $(\mathrm{mm})$ & \% Passing & Limit (MoRT\&H) (\%passing) \\
\hline 75 & 100 & 100 \\
\hline 53 & 84.56 & $80-100$ \\
\hline 26.5 & 77.20 & $55-90$ \\
\hline 9.5 & 66.09 & $35-65$ \\
\hline 4.75 & 48.30 & $25-55$ \\
\hline 2.36 & 43.68 & $20-40$ \\
\hline 0.425 & 26.63 & $10-25$ \\
\hline 0.075 & 3.71 & $3-10$ \\
\hline
\end{tabular}


Table 2. Gradation of WBM Component Layer Material (km 235.900)

\begin{tabular}{|c|c|c|}
\hline Sieve size (mm) & \% Passing & Limit (MoRT\&H) (\%passing) \\
\hline 90 & 100.00 & 100 \\
\hline 63 & 99.01 & $90-100$ \\
\hline 53 & 74.56 & $25-75$ \\
\hline 45 & 13.70 & $0-15$ \\
\hline 22.4 & 8.36 & $0-5$ \\
\hline
\end{tabular}

Table 3. Gradation of Screening Material of WBM Component Layer (km 235.900)

\begin{tabular}{|c|c|c|}
\hline Sieve size (mm) & \% Passing & Limit (MoRT\&H) (\%passing) \\
\hline 13.2 & 100.00 & 100 \\
\hline 11.2 & 96.03 & $95-100$ \\
\hline 5.6 & 25.01 & $15-35$ \\
\hline $180 \mu$ & 11.21 & $0-10$ \\
\hline
\end{tabular}

Table 4. Gradation of GSB Component Layer Material $(\mathrm{km} 233.800)$

\begin{tabular}{|c|c|c|}
\hline Sieve size (mm) & \% Passing & Limit (MoRT\&H) (\%passing) \\
\hline 75 & 100 & 100 \\
\hline 53 & 91.06 & $80-100$ \\
\hline 26.5 & 82.69 & $55-90$ \\
\hline 9.5 & 63.58 & $35-65$ \\
\hline 4.75 & 54.55 & $25-55$ \\
\hline 2.36 & 48.39 & $20-40$ \\
\hline 0.425 & 20.89 & $10-25$ \\
\hline 0.075 & 4.85 & $3-10$ \\
\hline
\end{tabular}

Table 5. Gradation of WBM Component Layer Material (km 233.800)

\begin{tabular}{|c|c|c|}
\hline Sieve size $(\mathrm{mm})$ & \% Passing & Limit (MoRT\&H) (\%passing) \\
\hline 90 & 100.00 & 100 \\
\hline 63 & 90.25 & $90-100$ \\
\hline 53 & 72.13 & $25-75$ \\
\hline 45 & 17.73 & $0-15$ \\
\hline 22.4 & 5.00 & $0-5$ \\
\hline
\end{tabular}

Table 6. Gradation of Screening Material of WBM Component Layer ( $\mathrm{km} 233.800)$

\begin{tabular}{|c|c|c|}
\hline Sieve size $(\mathrm{mm})$ & \% Passing & Limit (MoRT\&H) (\%passing) \\
\hline 13.2 & 100.00 & 100 \\
\hline 11.2 & 97.61 & $95-100$ \\
\hline 5.6 & 34.05 & $15-35$ \\
\hline $180 \mu$ & 13.67 & $0-10$ \\
\hline
\end{tabular}

Table 7. OMC \& MDD of WBM \& GSB Component Layer Martial

\begin{tabular}{|c|c|c|c|c|c|}
\hline \multirow{2}{*}{ Sr. No. } & \multirow{2}{*}{ Properties } & \multicolumn{2}{|c|}{$\mathrm{km} 233.800$} & \multicolumn{2}{c|}{$\mathrm{km} 235.900$} \\
\cline { 3 - 6 } & & WBM & GSB & WBM & GSB \\
\hline 1 & OMC (\%) & 6.000 & 6.000 & 6.000 & 6.000 \\
\hline 2 & MDD $\left(\mathrm{gm} / \mathrm{mm}^{3}\right)$ & 2.265 & 2.206 & 2.260 & 2.204 \\
\hline
\end{tabular}

Table 8. Calculation of Permeability of GSB Layer of km 233.800 and $\mathrm{km} 235.900$

\begin{tabular}{|c|c|c|c|}
\hline Sr. No. & Chainage & Permeability (cm/min) & Permeability (m/day) \\
\hline 1 & $\mathrm{Km} 233.800$ & 1.160043 & 16.70455 \\
\hline 2 & $\mathrm{Km} 235.900$ & 0.00075 & 0.010805 \\
\hline
\end{tabular}




\subsection{Field Study}

\subsubsection{Benkelman Beam Deflection Study}

Benkelman Beam Deflection Survey was carried out on the sections under consideration. The corrected characteristic deflection was calculated on the basis of IRC 81-1997, applying the correction for temperature variation and seasonal variation. The corrected characteristic deflections are given in the Table 9.

Table 9. Corrected Characteristic Deflections at Different Locations

\begin{tabular}{|c|c|c|c|c|}
\hline Location & \multicolumn{2}{|c|}{ Between Km 233.600 and 233.800 } & \multicolumn{2}{c|}{ Between Km 235.900 and 236.095 } \\
\hline Direction & $\begin{array}{c}\text { Rishikesh to } \\
\text { Shrinagar }\end{array}$ & $\begin{array}{c}\text { Shrinagar to } \\
\text { Rishikesh }\end{array}$ & $\begin{array}{c}\text { Rishikesh to } \\
\text { Shrinagar }\end{array}$ & $\begin{array}{c}\text { Shrinagar to } \\
\text { Rishikesh }\end{array}$ \\
\hline $\begin{array}{c}\text { Corrected Characteristic } \\
\text { Deflection (mm) }\end{array}$ & 0.41 & 0.41 & 0.61 & 0.48 \\
\hline
\end{tabular}

\subsubsection{Traffic Volume Count}

The details of traffic volume for the year 2012 were collected from Average Annual Daily Traffic based on Weekly Traffic Census as given in the Table 10 .

Table 10. Average Annual Daily Traffic Based on Weekly Traffic Census

\begin{tabular}{|c|c|c|c|c|c|c|c|}
\hline \multicolumn{8}{|c|}{ Average Annual Daily Traffic Based on Weekly Traffic Census } \\
\hline Date & \multicolumn{5}{|c|}{ Motorized vehicles } & \multicolumn{2}{|c|}{ Slow Vehicles } \\
\hline & $\begin{array}{c}\text { Cars, Jeeps, Vans, } \\
\text { Three Wheelers }\end{array}$ & Buses & LCV & $\mathrm{HCV}$ & $\begin{array}{l}\text { Motor Cycles } \\
\text { and Scooters }\end{array}$ & $\begin{array}{c}\text { Animal drawn } \\
\text { vehicles }\end{array}$ & Cycles \\
\hline 09-04-2012 & 2503 & 1376 & 450 & 676 & 1471 & 0 & 276 \\
\hline $10-04-2012$ & 1881 & 1449 & 444 & 667 & 1444 & 0 & 339 \\
\hline 11-09-2012 & 1485 & 1303 & 392 & 589 & 1248 & 0 & 304 \\
\hline 12-09-2012 & 1431 & 1248 & 375 & 562 & 1297 & 0 & 278 \\
\hline 13-04-2012 & 1410 & 1382 & 328 & 491 & 1319 & 0 & 247 \\
\hline $14-04-2012$ & 1323 & 1363 & 333 & 500 & 1203 & 0 & 307 \\
\hline $15-04-2012$ & 1273 & 1137 & 346 & 518 & 1212 & 0 & 313 \\
\hline Total Traffic & 11306 & 9258 & 2668 & 4003 & 9194 & 0 & 2064 \\
\hline Avg. Traffic & 1615 & 1322 & 381 & 572 & 1313 & 0 & 295 \\
\hline
\end{tabular}

Note: LCV - Light commercial vehicles, HCV - two axle heavy commercial vehicles

\section{Analysis of Results and Discussion}

Sample of pavement layer, which were collected from field, were tested in the laboratory. Also data of pavement deflection, traffic census, and roughness were measured for the year 2012 and predicted using relevant prediction models. On the basis of predicted value, VOC and overlay requirement were calculated and benefit of providing good drainage over poor drainage for the pavement section were quantified.

\subsection{Classification of Sub- Surface Drainage}

Sub-surface drainage condition of pavement was evaluated on the basis of the permeability results of GSB layer. Markow (2001) has classified sub-surface drainage quality of a pavement based on permeability of sub-base is given in Table 11.

Table 11. Classification of Sub- Surface Drainage

\begin{tabular}{|c|c|}
\hline Condition of sub-drainage & Permeability of sub-base \\
\hline Poor & $0.1 \mathrm{ft} /$ day $(0.03 \mathrm{~m} /$ day $)$ \\
\hline Fair & $100 \mathrm{ft} /$ day $(30.5 \mathrm{~m} /$ day $)$ \\
\hline Good & $10,000 \mathrm{ft} /$ day $(3050 \mathrm{~m} /$ day $)$ \\
\hline
\end{tabular}

It was further stated that a minimally acceptable value of sub-base permeability should lie between poor and fair values [0.1-100 $\mathrm{ft} /$ day (0.03-30.5 m/day)] if rainfall infiltration is not to cause substantial damage to the road pavement, and this should be aimed at in the selection of sub-base material. 
Grover and Veeraragavan (2010) mentioned that GSB layer should satisfy the permeability criteria of minimum 20m/day. In the present study, based on the permeability of GSB layer, section $\mathrm{km} 235.900$ was classified as poor drainage section and section $\mathrm{km}$ 233.800 was classified as good drainage section. Various possible sources of moisture/water entry in the pavements as observed include surface infiltration through cracks, rising ground water, seepage water through cut sections where ditches are shallow, and water penetrating through shoulders.

\subsection{Prediction of Pavement Performance}

In this study deflection and roughness have been taken as pavement performance parameters. Deflection and roughness values for year 2012 of the sections under study have been measured. Since the past cyclic data related to roughness and deflection was not available the prediction models developed by Reddy 1996, for National Highways and were adopted for this study.

\subsection{Deflection Progression Model}

The model developed by Reddy (1999) as given below was used for deflection prediction.

$$
\mathrm{D}_{\mathrm{i}}=\mathrm{iDEF}+0.07884\left[\left(\mathrm{~N}_{\mathrm{t}} \times \text { Age }\right)^{\mathrm{iDEF}}\right], 0.44<\mathrm{iDEF}<0.6
$$

where, $\mathrm{iDEF}=$ initial deflection $(\mathrm{mm}), \mathrm{D}_{\mathrm{t}}=$ Corrected characteristic rebound deflection $(\mathrm{mm})$ at any time $\mathrm{t}, \mathrm{N}_{\mathrm{t}}=$ cumulative standard axles (millions) at t.

\subsubsection{Roughness Progression Model}

Roughness progression model as developed by Reddy (1996) as given below was used for prediction of roughness. Roughness progression model is a function of initial roughness, age, deflection and traffic. Cumulative standard axles have been calculated as per IRC: $37-2001$. The lane distribution factor is taken as 0.75 , the vehicle damage factor is taken as 4.5 and annual traffic growth is taken as $7.5 \%$.

$$
\text { UIt }=\mathrm{iUI}\left[1+0.3012\left(\mathrm{~N}_{\mathrm{t}} * \mathrm{DEF}_{0}\right)^{0.08 \mathrm{Age}}\right]
$$

Where, UIt $=$ Roughness index at any time $\mathrm{t}(\mathrm{mm} / \mathrm{km}), \mathrm{iUI}=$ Initial roughness index $(\mathrm{mm} / \mathrm{km})$, Age $=$ Age of the pavement (years), $\mathrm{Nt}=$ Cumulative standard axles (millions) $\mathrm{t}, \mathrm{DEF}_{0}=$ Deflection in $\mathrm{mm}$

Using above prediction models deflection and roughness of road sections for ten years was predicted for good and poor drainage section separately, the trends of which are shown in Figure 4 \& 5 respectively. It can be observed from the Figure 4 that predicted deflection value for year 2022 for good drainage section is $1.39 \mathrm{~mm}$ and for poor drainage section is $3.642 \mathrm{~mm}$, which is about 162\% more than that of good drainage section. Also Figure 5 indicates the roughness values for year 2022 for good drainage section is $8374 \mathrm{~mm} / \mathrm{km}$ and for poor drainage section is $5787 \mathrm{~mm} / \mathrm{km}$, which is about $45 \%$ more than that of good drainage section. This indicates that poor drainage affects significantly to the deterioration of pavement condition. Maximum permissible values of roughness as per IRC: SP: 16-2004, for road surfaces are given in Table 12.

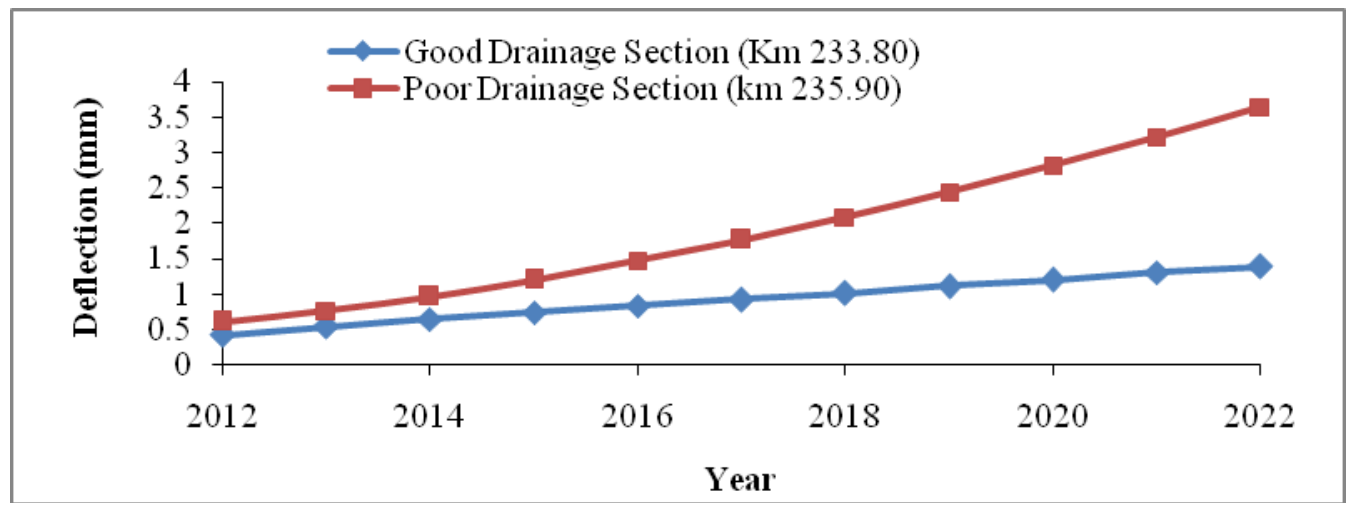

Figure 4: Predicted Deflections and Roughness for Good Drainage Section (km 233.800) 


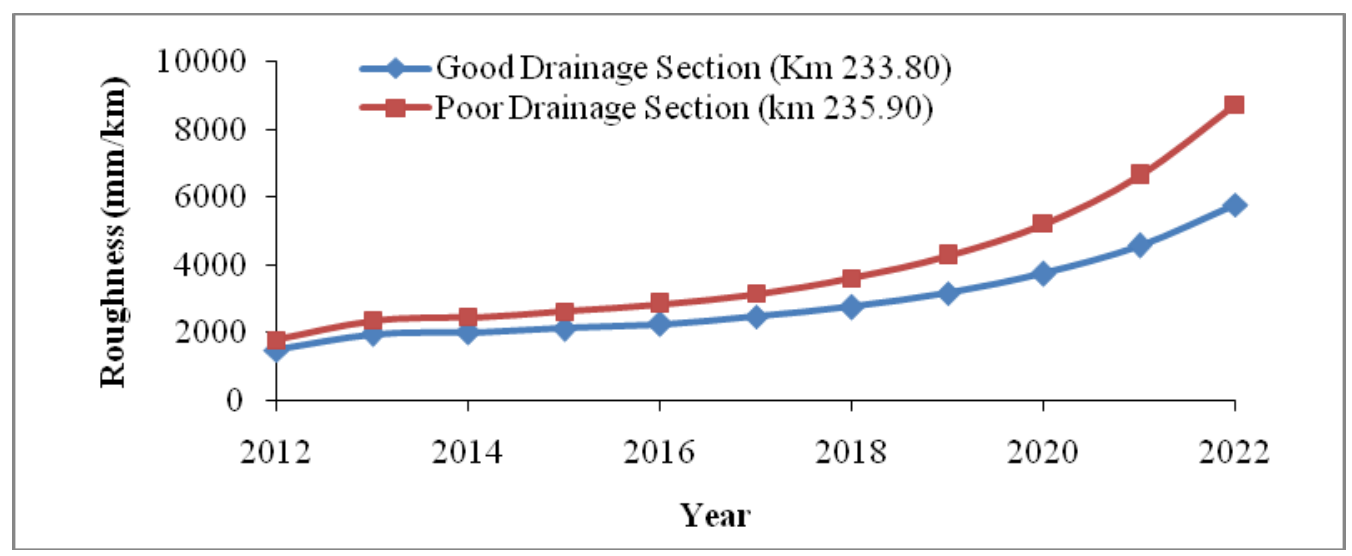

Figure 5: Predicted Deflections and Roughness for Poor Drainage Section (km 235.900)

Table 12. Maximum Permissible Values of Roughness (mm/km) for Road Surface

\begin{tabular}{|c|l|c|c|c|}
\hline S. No. & \multicolumn{1}{|c|}{ Type of Surface } & \multicolumn{3}{|c|}{ Condition of Road Surface } \\
\cline { 3 - 5 } & & Good & Average & Poor \\
\hline 1 & Surface dressing & $<3500$ & $3500-4500$ & $>4500$ \\
\hline 2 & Open Graded premix Carpet & $<3000$ & $3000-4000$ & $>4000$ \\
\hline 3 & Mix Seal surfacing & $<3000$ & $3000-4000$ & $>4000$ \\
\hline 4 & Semi-Dense Bituminous Concrete & $<2500$ & $2500-3500$ & $>3500$ \\
\hline 5 & Bituminous Concrete & $<2000$ & $2000-3000$ & $>3000$ \\
\hline 6 & Cement Concrete & $<2200$ & $2200-3000$ & $>3000$ \\
\hline
\end{tabular}

The suitable maintenance strategies have been selected for the section based on the trigger values of roughness and deflection. The trigger value for roughness and deflection as adopted for assigning the thin overlay treatment were $2500 \mathrm{~mm} / \mathrm{km}$ and $1 \mathrm{~mm}$ respectively.

\subsection{Overlay Requirement}

Thin overlay is required as soon as the pavement performance reaches the trigger point i.e deflection of $1 \mathrm{~mm}$ and roughness value of $2500 \mathrm{~mm} / \mathrm{km}$. The overlay requirement of good and poor drainage pavement section has been estimated and given in Figure 6 and Figure 7 respectively. It can be observed that frequency of overlay required for good drainage pavement sections was one during the design period of 10 years i.e in year 2018, while for poor drainage pavement section was two i.e. in year 2015 \& 2019. The roughness values measured in year 2012 was after one year of laying overlay. Hence for the year 2018 (for good drainage section) and 2015 \& 2019 (for poor drainage section) after the construction of an overlay, it was assumed that the roughness values will be lower than that measured in year 2012.

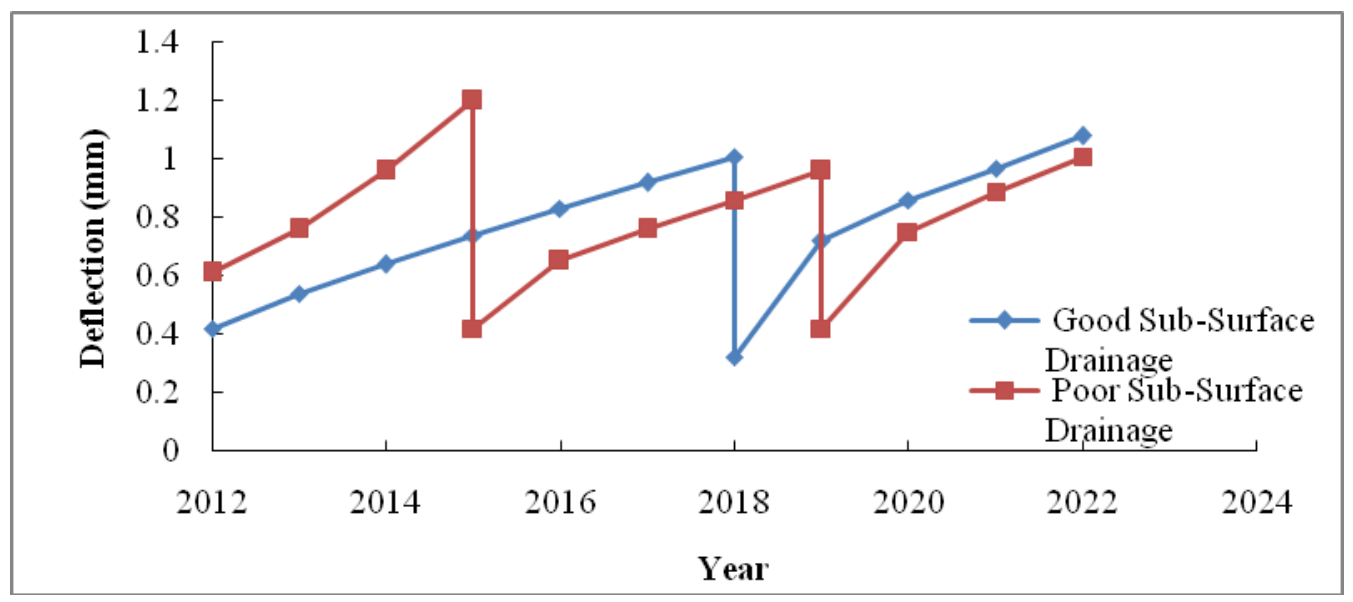

Figure 6: Deflection Progression for Thin Overlay Strategy with Good \& Poor Sub-Surface Drainage 


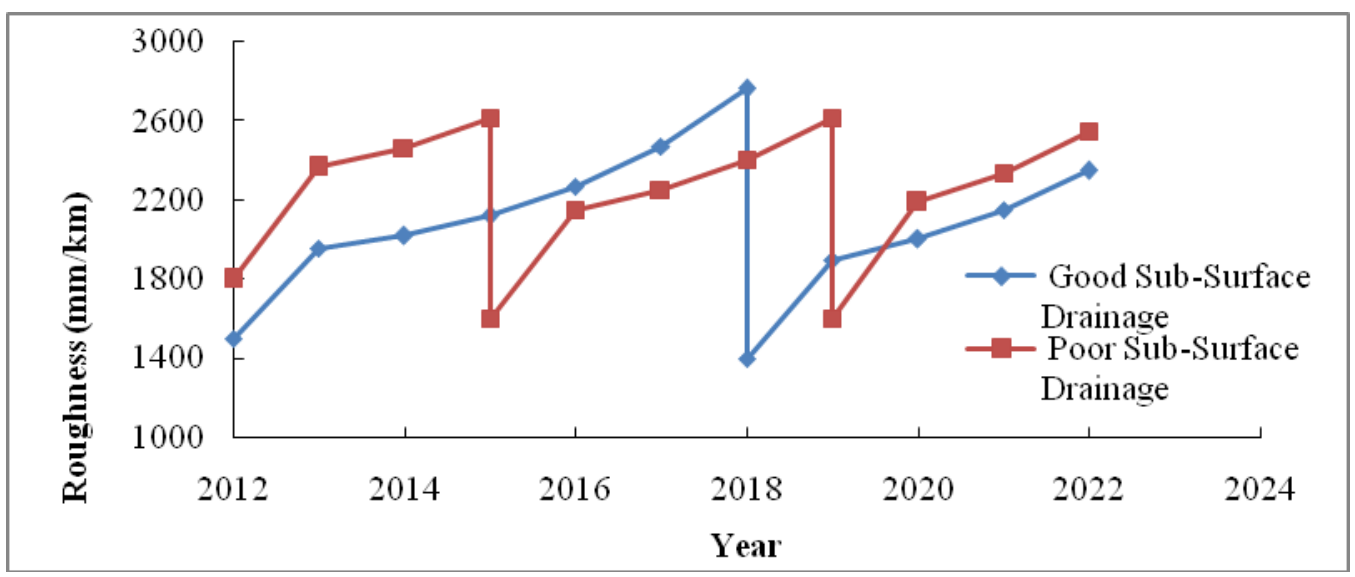

Figure 7: Roughness Progression for Thin Overlay Strategy with Good \& Poor Sub-Surface Drainage

\subsection{Estimation of VOC}

Vehicle operating cost equations developed by Reddy et al. (2003) for different classes of vehicle were used in the computation of vehicle operation cost per $\mathrm{km}$. The vehicle classifications covered are new brand cars, old brand cars, two-wheelers, buses, LCV, HCV, and multi axle heavy commercial vehicles (MAV). The rise and fall value is taken as $2.5 \mathrm{~m} / \mathrm{km}$. The equation used for two lanes undivided National Highway is given in Table 13.

Table 13. Equations for Calculating Vehicle Operating Cost (Rs/Km/Vehicle) for Two-Lane Highway

\begin{tabular}{|c|c|}
\hline Vehicle Type & VOC equations \\
\hline New technology cars & loge $\mathrm{VOC}=.93-0.134 * \mathrm{~W}+0.00009256 * \mathrm{RG}+0.01411 * \mathrm{RF}$ \\
\hline Buses & loge $\mathrm{VOC}=1.705-0.073 * \mathrm{~W}+0.00004718 * \mathrm{RG}+0.01225 * \mathrm{RG}$ \\
\hline Old Technology cars & loge $\mathrm{VOC}=1.112-0.114 * \mathrm{~W}+0.00009774 * \mathrm{RG}+0.01251 * * \mathrm{RF}$ \\
\hline Light commercial vehicles & loge $\mathrm{VOC}=1.849-0.041 * \mathrm{~W}+0.00002822 * \mathrm{RG}+0.01212 * \mathrm{RF}$ \\
\hline Heavy commercial vehicles & loge $\mathrm{VOC}=2.092-0.061 * \mathrm{~W}+0.00004047 * \mathrm{RG}+0.00938 * \mathrm{RF}$ \\
\hline Multy-Axle commercial-vehicle & loge $\mathrm{VOC}=2.561-0.053 * \mathrm{~W}+0.00003039 * \mathrm{RG}+0.01337 * \mathrm{RF}$ \\
\hline Two wheelers & loge $\mathrm{VOC}=-0.253-0.118 * \mathrm{~W}+0.00001282 * \mathrm{RG}+0.01312 * \mathrm{RF}$ \\
\hline
\end{tabular}

VOC has been calculated considering a VOC growth rate of $9 \%$ and then a discount rate of $10 \%$ is applied (Grover and Veeraragavan 2010). The cost associated with each treatment at different time periods during the design life is converted to present worth at discount rate of $10 \%$. Difference in VOC for do-nothing strategy and post treatment strategy is considered as the benefit. VOC (in Lacks) for Do- Nothing Strategy for pavement section with good drainage is given in Table 14. VOC for Do- Nothing Strategy for pavement section with poor drainage has been given in Table 15. Pavement sections for do nothing strategy for good drainage section was found to reach the threshold value of roughness in 2018 that is after six years, and for poor drainage section in 2015 and 2019. Thin overlay will be applied at that time. VOC for both the cases has been calculated considering the future maintenance and is given in the Table 16 \& 17. The comparison of present worth of total VOC for both good and poor drainage sections and for both maintenance strategies applied is shown in Figure 8. It can be observed that the VOC value does not vary much in case of Do-nothing strategy for both type of drainage section, but in case of Thin-overlay treatment the total VOC value for poor drainage section is about $19 \%$ more than that of good drainage section. This is because the pavement deteriorates faster due to poor drainage and the frequency of maintenance treatment required for poor drainage section is more than good drainage section. 
Table 14. Vehicle Operating Cost (In Lacks) for Do- Nothing Strategy for Pavement Section with Good Drainage

\begin{tabular}{|c|c|c|c|c|c|c|c|c|}
\hline \multirow[b]{2}{*}{ Year } & \multicolumn{5}{|c|}{ VOC (Rs./km/year) (in lacks) } & \multirow[b]{2}{*}{$\begin{array}{l}\text { Total } \\
\text { VOC }\end{array}$} & \multirow[b]{2}{*}{$\begin{array}{l}\text { VOC at } \\
\text { growth rate } \\
\text { of } 9 \% \text { and } \\
\text { Inflation } \\
\text { factor1.8 }\end{array}$} & \multirow[b]{2}{*}{$\begin{array}{c}\text { Present } \\
\text { Worth at } \\
\text { discount } \\
\text { rate of } \\
10 \%\end{array}$} \\
\hline & $\begin{array}{l}\text { Cars, Jeeps, } \\
\text { Vans, Three } \\
\text { Wheelers } \\
\text { (new } \\
\text { technology) }\end{array}$ & Buses & $\begin{array}{c}\text { Light } \\
\text { commercial } \\
\text { Vehicle }\end{array}$ & $\begin{array}{c}\text { Heavy } \\
\text { commer } \\
\text { cial } \\
\text { Vehicle }\end{array}$ & $\begin{array}{l}\text { Motor } \\
\text { Cycles } \\
\text { and } \\
\text { Scooters }\end{array}$ & & & \\
\hline 2012 & 6.92 & 17.48 & 7.13 & 12.00 & 2.04 & 45.57 & 82.03 & 82.03 \\
\hline 2013 & 7.76 & 18.88 & 7.77 & 13.15 & 2.33 & 49.87 & 97.85 & 88.96 \\
\hline 2014 & 8.39 & 20.39 & 8.36 & 14.17 & 2.52 & 53.84 & 115.14 & 95.15 \\
\hline 2015 & 9.10 & 22.04 & 9.02 & 15.29 & 2.75 & 58.20 & 135.68 & 101.93 \\
\hline 2016 & 9.92 & 23.83 & 9.73 & 16.54 & 3.01 & 63.03 & 160.16 & 109.39 \\
\hline 2017 & 10.87 & 25.78 & 10.52 & 17.93 & 3.32 & 68.42 & 189.50 & 117.67 \\
\hline 2018 & 12.00 & 27.90 & 11.40 & 19.50 & 3.71 & 74.51 & 224.94 & 126.97 \\
\hline 2019 & 13.40 & 30.21 & 12.40 & 21.31 & 4.20 & 81.52 & 268.25 & 137.65 \\
\hline 2020 & 15.20 & 32.73 & 13.55 & 23.45 & 4.87 & 89.80 & 322.06 & 150.24 \\
\hline 2021 & 17.64 & 35.48 & 14.91 & 26.07 & 5.82 & 99.93 & 390.67 & 165.68 \\
\hline 2022 & 21.20 & 38.48 & 16.59 & 29.43 & 7.31 & 113.01 & 481.56 & 185.66 \\
\hline & & & & & & Total & 2467.84 & 1361.35 \\
\hline
\end{tabular}

Table 15. Vehicle Operating Cost (in Lacks) for Do- Nothing Strategy for Pavement Section with Poor Drainage

\begin{tabular}{|c|c|c|c|c|c|c|c|c|}
\hline \multirow[b]{2}{*}{ Year } & \multicolumn{5}{|c|}{ VOC (Rs./km/year) (in lacks) } & \multirow[b]{2}{*}{$\begin{array}{l}\text { Total } \\
\text { VOC }\end{array}$} & \multirow{2}{*}{$\begin{array}{l}\text { VOC at } \\
\text { growth } \\
\text { rate of } \\
9 \% \text { and } \\
\text { Inflation } \\
\text { factor } 1.8\end{array}$} & \multirow[b]{2}{*}{$\begin{array}{c}\text { Present } \\
\text { Worth at } \\
\text { discount } \\
\text { rate of } \\
5 \%\end{array}$} \\
\hline & $\begin{array}{c}\text { Cars, Jeeps, } \\
\text { Vans, Three } \\
\text { Wheelers (new } \\
\text { technology) }\end{array}$ & Buses & $\begin{array}{c}\text { Light } \\
\text { commercial } \\
\text { Vehicle }\end{array}$ & $\begin{array}{c}\text { Heavy } \\
\text { commerci } \\
\text { al Vehicle }\end{array}$ & $\begin{array}{c}\text { Motor } \\
\text { Cycles and } \\
\text { Scooters }\end{array}$ & & & \\
\hline 2012 & 7.11 & 17.48 & 7.19 & 12.15 & 2.12 & 46.05 & 82.90 & 82.89 \\
\hline 2013 & 8.06 & 18.88 & 7.86 & 13.36 & 2.45 & 50.61 & 99.29 & 90.264 \\
\hline 2014 & 8.74 & 20.39 & 8.47 & 14.42 & 2.67 & 54.70 & 116.98 & 96.67 \\
\hline 2015 & 9.53 & 22.04 & 9.14 & 15.60 & 2.93 & 59.25 & 138.11 & 103.76 \\
\hline 2016 & 10.46 & 23.83 & 9.89 & 16.92 & 3.24 & 64.35 & 163.49 & 111.67 \\
\hline 2017 & 11.58 & 25.78 & 10.73 & 18.43 & 3.63 & 70.15 & 194.27 & 120.62 \\
\hline 2018 & 12.99 & 27.90 & 11.68 & 20.18 & 4.14 & 76.89 & 232.10 & 131.01 \\
\hline 2019 & 14.84 & 30.21 & 12.79 & 22.28 & 4.84 & 84.96 & 279.56 & 143.46 \\
\hline 2020 & 17.43 & 32.73 & 14.13 & 24.90 & 5.89 & 95.07 & 340.98 & 159.07 \\
\hline 2021 & 21.34 & 35.48 & 15.80 & 28.34 & 7.58 & 108.55 & 424.36 & 179.97 \\
\hline \multirow[t]{2}{*}{2022} & 27.85 & 38.48 & 18.02 & 33.16 & 10.68 & 128.19 & 546.27 & 210.61 \\
\hline & & & & & & Total & 2618.30 & 1430.01 \\
\hline
\end{tabular}


Table 16. Vehicle Operating Cost (in Lacks) for Thin Overlay Strategy for Pavement Section with Good Drainage

\begin{tabular}{|c|c|c|c|c|c|c|c|c|}
\hline \multirow[b]{2}{*}{ Year } & \multicolumn{5}{|c|}{ VOC (Rs./km/year) (in lacks) } & \multirow[b]{2}{*}{$\begin{array}{l}\text { Total } \\
\text { VOC }\end{array}$} & \multirow{2}{*}{$\begin{array}{l}\text { VOC at } \\
\text { growth } \\
\text { rate of } \\
9 \% \text { and } \\
\text { Inflation } \\
\text { factor } 1.8\end{array}$} & \multirow{2}{*}{$\begin{array}{c}\text { Present } \\
\text { Worth at } \\
\text { discount } \\
\text { rate of } \\
10 \%\end{array}$} \\
\hline & $\begin{array}{c}\text { Cars, Jeeps, } \\
\text { Vans, Three } \\
\text { Wheelers (new } \\
\text { technology) }\end{array}$ & Buses & $\begin{array}{c}\text { Light } \\
\text { commercial } \\
\text { Vehicle }\end{array}$ & $\begin{array}{c}\text { Heavy } \\
\text { commercial } \\
\text { Vehicle }\end{array}$ & $\begin{array}{l}\text { Motor } \\
\text { Cycles } \\
\text { and } \\
\text { Scooters }\end{array}$ & & & \\
\hline 2012 & 6.92 & 17.48 & 7.13 & 12.00 & 2.04 & 45.57 & 82.03 & 82.03 \\
\hline 2013 & 7.76 & 18.88 & 7.77 & 13.15 & 2.33 & 49.87 & 97.85 & 88.96 \\
\hline 2014 & 8.39 & 20.39 & 8.36 & 14.17 & 2.52 & 53.84 & 115.14 & 95.15 \\
\hline 2015 & 9.10 & 22.04 & 9.02 & 15.29 & 2.75 & 58.20 & 135.68 & 101.93 \\
\hline 2016 & 9.92 & 23.83 & 9.73 & 16.54 & 3.01 & 63.03 & 160.16 & 109.39 \\
\hline 2017 & 10.87 & 25.78 & 10.52 & 17.93 & 3.32 & 68.42 & 189.50 & 117.67 \\
\hline 2018 & 10.68 & 27.90 & 11.00 & 18.53 & 3.15 & 71.26 & 215.12 & 121.43 \\
\hline 2019 & 12.06 & 30.21 & 12.01 & 20.35 & 3.63 & 78.26 & 257.50 & 132.14 \\
\hline 2020 & 13.10 & 32.73 & 12.95 & 21.98 & 3.96 & 84.71 & 303.84 & 141.74 \\
\hline 2021 & 14.29 & 35.48 & 13.98 & 23.78 & 4.34 & 91.87 & 359.15 & 152.32 \\
\hline 2022 & 15.67 & 38.48 & 15.13 & 25.78 & 4.80 & 99.86 & 425.53 & 164.06 \\
\hline & & & & & & Total & 2341.50 & 1306.82 \\
\hline
\end{tabular}

Table 17. Vehicle Operating Cost (in Lacks) for Thin Overlay Strategy for Pavement Section with Poor Drainage

\begin{tabular}{|c|c|c|c|c|c|c|c|c|}
\hline \multirow[b]{2}{*}{ Year } & \multicolumn{5}{|c|}{ VOC (Rs./km/year) (in lacks) } & \multirow[b]{2}{*}{$\begin{array}{l}\text { Total } \\
\text { VOC }\end{array}$} & \multirow{2}{*}{$\begin{array}{l}\text { VOC at } \\
\text { growth } \\
\text { rate of } \\
9 \% \text { and } \\
\text { Inflation } \\
\text { factor } 1.8\end{array}$} & \multirow[b]{2}{*}{$\begin{array}{c}\text { Present } \\
\text { Worth at } \\
\text { discount } \\
\text { rate of } \\
10 \%\end{array}$} \\
\hline & $\begin{array}{c}\text { Cars, Jeeps, } \\
\text { Vans, Three } \\
\text { Wheelers (new } \\
\text { technology) }\end{array}$ & Buses & $\begin{array}{c}\text { Light } \\
\text { commercial } \\
\text { Vehicle }\end{array}$ & $\begin{array}{c}\text { Heavy } \\
\text { commercial } \\
\text { Vehicle }\end{array}$ & $\begin{array}{l}\text { Motor } \\
\text { Cycles } \\
\text { and } \\
\text { Scooters } \\
\end{array}$ & & & \\
\hline 2012 & 7.11 & 17.48 & 7.19 & 12.15 & 2.12 & 46.05 & 82.90 & 82.90 \\
\hline 2013 & 8.06 & 18.88 & 7.86 & 13.36 & 2.45 & 50.61 & 99.29 & 90.26 \\
\hline 2014 & 8.74 & 20.39 & 8.47 & 14.42 & 2.67 & 54.70 & 116.98 & 96.67 \\
\hline 2015 & 8.67 & 22.04 & 8.88 & 14.97 & 2.57 & 57.14 & 133.20 & 100.08 \\
\hline 2016 & 9.81 & 23.83 & 9.70 & 16.46 & 2.96 & 62.77 & 159.48 & 108.93 \\
\hline 2017 & 10.65 & 25.78 & 10.46 & 17.77 & 3.23 & 67.89 & 188.02 & 116.75 \\
\hline 2018 & 11.61 & 27.90 & 11.29 & 19.22 & 3.54 & 73.56 & 222.07 & 125.35 \\
\hline 2019 & 11.58 & 30.21 & 11.86 & 20.00 & 3.43 & 77.09 & 253.65 & 130.16 \\
\hline 2020 & 13.15 & 32.73 & 12.97 & 22.01 & 3.98 & 84.84 & 304.30 & 141.96 \\
\hline 2021 & 14.33 & 35.48 & 14.00 & 23.81 & 4.36 & 91.98 & 359.59 & 152.50 \\
\hline \multirow[t]{2}{*}{2022} & 15.71 & 38.48 & 15.14 & 25.81 & 4.82 & 99.96 & 425.95 & 164.22 \\
\hline & & & & & & Total & 2345.44 & 1309.79 \\
\hline
\end{tabular}

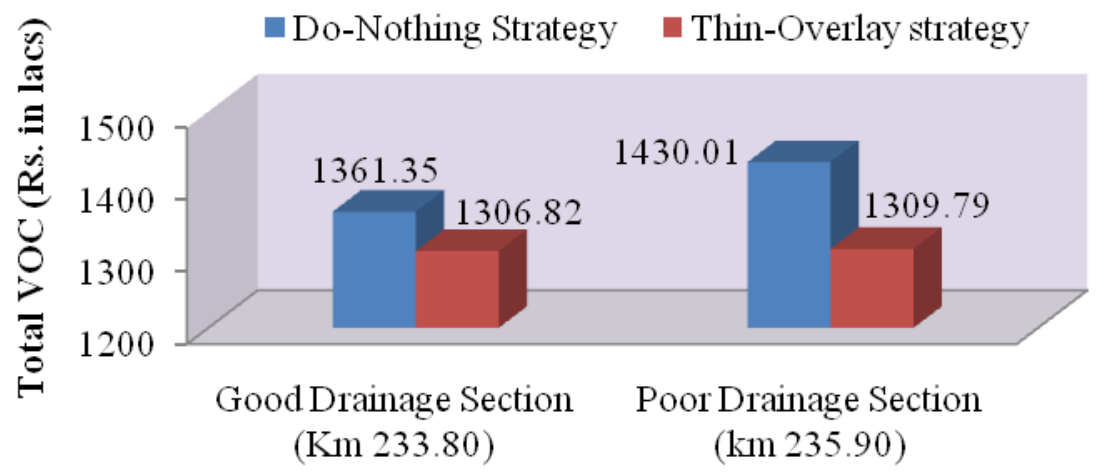

Figure 8: VOC for Good \& Poor Drainage Sections 
5.6 Quantification of Benefits due to Timely Maintenance by computation of Road User Costs for Pavement Section with Poor and Good Drainage

Agency cost per km of pavement for thin overlay has been calculated and are given in Table 18.

Table 18. Agency Cost for Thin Overlay per km of Pavement

\begin{tabular}{|c|c|c|c|c|c|c|}
\hline Sr. No. & Year & $\begin{array}{c}\text { Discounted Cost at 10\% in } \\
\text { Lack per two lanes km }\end{array}$ & \multicolumn{2}{|c|}{$\begin{array}{c}\text { Yverlay Cost \& Discounted Cost at } \\
10 \% \text { in Lack per two lanes km }\end{array}$} \\
\hline 1 & 2012 & 17.08 & 0.00 & & & \\
\hline 2 & 2013 & 15.53 & 1.00 & & & \\
\hline 3 & 2014 & 14.12 & 2.00 & & & \\
\hline 4 & 2015 & 12.83 & 3.00 & 20.92 & & \\
\hline 5 & 2016 & 11.67 & 4.00 & 19.02 & & \\
\hline 6 & 2017 & 10.61 & 5.00 & 17.29 & & \\
\hline 7 & 2018 & 9.64 & 6.00 & 15.72 & 25.63 & \\
\hline 8 & 2019 & 8.76 & 7.00 & 14.29 & 23.30 & 27.43 \\
\hline 9 & 2020 & 7.97 & 8.00 & 12.99 & 21.18 & 24.93 \\
\hline 10 & 2021 & 7.24 & 9.00 & 11.81 & 19.26 & 22.67 \\
\hline 11 & 2022 & 6.59 & 10.00 & 10.74 & 17.51 & 20.61 \\
\hline
\end{tabular}

The benefit per unit agency cost per km for overlay strategy for pavement section with good and poor drainage is calculated and is given in the Table 19 and 20 respectively.

Table 19. Benefit per Unit Agency Cost per km for Overlay Strategy for Pavement Section with Good Drainage

\begin{tabular}{|c|l|c|c|}
\hline Sr. No. & \multicolumn{1}{|c|}{ Parameters } & Rs. (lack) & Remarks \\
\hline 1 & Vehicle Operating Costs (VOC) for Do -Nothing strategy & 1361.35 & ---- \\
\hline 2 & Vehicle Operating Costs (VOC) for overlay strategy & 1306.82 & ---- \\
\hline 3 & Benefit & 54.53 & Sl No.1- Sl No. 2 \\
\hline 4 & $\begin{array}{l}\text { Agency cost for thin overlay per km of pavement } \\
\text { as shown in Table 18) }\end{array}$ & 35.27 & $\begin{array}{c}\text { Cost of construction of 40 mm BC } \\
\text { overlay (9.64+25.63) }\end{array}$ \\
\hline 5 & $\begin{array}{l}\text { Benefit per unit agency cost per km (during 10 years } \\
\text { service life of pavement) due to timely maintenance }\end{array}$ & 1.55 & Sl No3/ Sl No 4 \\
\hline
\end{tabular}

Table 20. Benefit per Unit Agency Cost per km for Overlay Strategy for Pavement Section with Poor Drainage

\begin{tabular}{|c|c|c|c|}
\hline Sr. No. & Parameters & Rs. (lack) & Remarks \\
\hline 1 & Vehicle Operating Costs (VOC) for Do -Nothing strategy & 1430.01 & ---- \\
\hline 2 & Vehicle Operating Costs (VOC) for overlay strategy & 1309.79 & ---- \\
\hline 3 & Benefit & 120.22 & Sl No. 1- Sl No. 2 \\
\hline 4 & $\begin{array}{l}\text { Agency cost for thin overlay per km of pavement } \\
\text { (as shown in Table 18) }\end{array}$ & 61.18 & $\begin{array}{l}\text { Cost of construction of } 40 \mathrm{~mm} \mathrm{BC} \\
\text { overlay }\end{array}$ \\
\hline 5 & $\begin{array}{l}\text { Benefit per unit agency cost per km (during } 10 \text { years } \\
\text { service life of pavement) due to timely maintenance }\end{array}$ & 1.96 & Sl No3/ Sl No 4 \\
\hline
\end{tabular}

Comparisons of benefits of thin overlay between good drainage and poor drainage are given in Table 21 . 
Table 21. Comparison of Results of Quantification of Benefits Due to Thin Overlay Treatment for Pavement Sections with Good Drainage vs. Poor Drainage

\begin{tabular}{|c|l|c|c|}
\hline Sr. No. & \multicolumn{1}{|c|}{ Quantification of Benefits } & Good drainage & Poor drainage \\
\hline 1 & Computation of road User Costs Method & & \\
\hline a) & VOC for Do- Nothing Strategy, Rs lack & 1361.35 & 1430.01 \\
\hline b) & VOC for thin overlay Strategy, Rs lack & 1306.82 & 1309.79 \\
\hline c) & Benefit per km, Rs Lack & 54.53 & 120.22 \\
\hline d) & Agency Cost for Thin Overlay treatment per km & 35.27 & 61.18 \\
\hline e) & Benefit per unit agency cost per km in lack & 1.55 & 1.96 \\
\hline
\end{tabular}

\section{Conclusions and Recommendations}

\subsection{Conclusions}

Based on the present study following conclusions have been drawn:

1. Primary cause of premature failure of the pavement sections was found to be poor sub-surface drainage due to water entering the pavement surface infiltration through cracks, rising ground water, seepage water through, and water penetrating through shoulders and large percentage of fines in GSB layer preventing the effective drainage of pavement layer.

2. The rate of pavement deterioration was observed faster in case of pavement sections with low values of permeability.

3. The agency cost as calculated for poor drainage section is Rs. 61.18 lacks $/ \mathrm{km}$ and that of the good drainage surface is Rs. 35.27 lacks $/ \mathrm{km}$ that indicates that the agency cost of poor drainage section is more than that of the good drainage surface.

4. The pavement section with good drainage requires thin overlay treatment only once in a design period of 10 years where as poor drainage pavement section needs the thin overlays treatments twice during the same design period.

5. It was observed that the VOC for Do- Nothing strategy of poor drainage section was Rs. 1430.01 lacks $/ \mathrm{km}$ which is higher than that of the Do- Nothing strategy of good drainage section which was Rs. 1361.35lacks/km lacks. There was saving of Rs.68.66 lacks/km.

6. It was observed that the VOC for overlay strategy of poor drainage section was Rs. 1309.79 lacks/km which is higher than that of the overlay strategy of good drainage section which was Rs. 1306.82 lacks $/ \mathrm{km}$. In this case there was a saving of 2.97 lacks/km.

7. The hill side deflection of the half width of the pavement is observed more than that of other half of the pavement of same stretch of the poor drainage section.

\subsection{Recommendations}

1. Proper care should be given to the surface and sub-surface drainage of pavement during construction of the pavement.

2. Pavement deterioration model should be developed including the drainage parameter.

3. Periodic maintenance and inspection of the surface drainage system should be carried out and stretches where water stagnates either in the side drain or on the pavement surface should be identified for immediate corrective measures.

\section{Nomenclature}

NH - National Highway

WBM - Water Bound Macadam

GSB - Granular Sub-base

VOC - Vehicle Operating Cost

BBD - Benkelman Beam Deflection

IRC - Indian Roads congress

OMC - Optimum Moisture Content

MDD -Maximum Dry Density

MoRT\&H - Ministry of Road Transport \& Highways

AADT - Annual Average Daily Traffic

iDEF $=$ initial deflection $(\mathrm{mm})$

$\mathrm{D}_{\mathrm{t}}=$ Corrected characteristic rebound deflection $(\mathrm{mm})$ at any time $\mathrm{t}$

$\mathrm{N}_{\mathrm{t}}=$ cumulative standard axles (millions) at $\mathrm{t}$.

UIt $=$ Roughness index at any time $\mathrm{t}(\mathrm{mm} / \mathrm{km})$ 
$\mathrm{iUI}=$ Initial roughness index $(\mathrm{mm} / \mathrm{km})$

Age $=$ Age of the pavement (years)

$\mathrm{DEF}_{0}=$ Deflection in $\mathrm{mm}$

\section{References}

Anderson, D.A., Huebner, R.S., Read, J.R., Warner, J.C., and Henry, J.J., 1998. Improved Surface Drainage of Pavements. NCHRP Web Documents 16, Project 1-29, Final Report.

Birgission, B., and Roberrson, R., 2000. Drainage of Pavement Base Material- Design and Construction Issues, Transportation Research Record 1708, TRB, Washington, D.C., pp.11-18.

Grover, S. (Lt. Col.) \& Veeraragavan, A., 2010. Quantification of Benefits of Improved Pavement Performance Due to Good Drainage, Journal of Indian Roads Congress, IRC, Vol. 71-1, pp.77 - 99.

IRC: 37, 2001. Guidelines for the Design of Flexible Pavements, The Indian Road Congress, New Delhi- 110011.

IRC: 81, 1997. Guidelines for Strengthening of Flexible Pavements Using Benkelman Beam Deflection Techniques. The Indian

Road Congress, Jamnagar House, Shahjahan Road, New Delhi- 110011.

IRC: SP: 16, 2000. Guidelines for Surface Evenness of Highway Pavements. The Indian Road Congress, New Delhi- 110011.

IRC: SP: 50, 1999. Guidelines of Urban Drainage, The Indian Road Congress, New Delhi- 110011.

Jain, S.S., Gupta, A.K., and Sanjeev, R., 1992. Study of Influencing Parameters for Efficient Maintenance Management of Flexible Pavements, IRC Journal, Vol 53-1, pp. 93-143.

Li, H., J. Harvey and D. Jones 2012. Developing a Mechanistic-Empirical Design Procedure for Fully Permeable Pavement under

Heavy Traffic. Transportation Research Record. 2305, pp.83-94.

Li, H., J. Harvey, J. Holland and M. Kayhanian 2013. The Use of Reflective and Permeable Pavement Strategies for Heat Island Mitigation and Storm water Management. Environmental Research Letters, Vol. 8, 015023, pp.14.

Markow, M. J. 1982. Simulating Pavement Performance under Various Moisture Conditions, Transportation Research Record 849, TRB, Washington, D.C., pp. 24-29.

Reddy, B.B., 1996, “Development of Failure Criteria for Flexible Pavements”, PhD Thesis, Bangalore University, Bangalore.

Reddy, B.B., Nagaraju, k., and Veeraragavan, A., 1999. Practical Application of Flexible Pavement Deterioration Models, Highway Research Bulletin, No.61.

Reddy, T.S., Velmurugan, S., Madhu, E., Ramalingaiah, A.N. 2003. Updation of Road User Cost and Revised Software for Revaluation of Highway Project, Journal of the India Roads Congress, Volume 64-2.

Rokade, S., Agrawal, P.K., and Shrivastava, R., 2012. Study on Drainage Related Performance of Flexible Pavements, International Journal of Advanced Engineering Technology, Vol. II, Issue January- March, 2012, pp.334-337.

Shah, Y. U., Jain, S.S., Jain, M.K. and Tiwari, D. 2012. Urban Roadway Drainage Issues and Its Management - A Key Component of Urban PMS, Proceedings of International Conference on Environmentally Sustainable Urban Ecosystems (ENSURE 2012), Indian Institute of Technology Guwahati, India.

\section{Biographical notes}

Prashant Kumar Azad did his B.E. in 1996 from Bihar College of Engineering (now NIT) Patna. Later he cleared IES in 1998 and joined Border Roads Organization as Assistant Executive Engineer. He was promoted to Executive Engineer in 2008. He has worked on many projects like Zaranj in Afghanistan. He has handled various projects in hilly roads in India during his tenure of thirteen years of job. Presently Mr. Prashant is pursuing his M.Tech at Department of Civil Engineering, IIT Roorkee as a sponsored student.

Yogesh U. Shah did his B.E. in 2002 from Maharaja Sayajirao University, Baroda. Later he did his M.E degree in Highways and Transportation from the same university in 2004. He has a teaching experience of about six years where he taught various subjects of Civil Engineering to graduate and post graduate students. Presently Mr. Shah is pursuing his PhD programme at Centre for Transportation Systems, IIT Roorkee. His area of research is pavement management system for urban roads. He has published two paper each in national and international journal and seven papers in international conferences from his ongoing research work.

Prof. Jain has Teaching and Research experience of three decades in Transportation Engineering, Highway Infrastructure and Transportation Systems. Prof. Jain has contributed over 400 research papers in Indian and Foreign Journals and Conference Proceedings and also published one Book. He has completed 25 sponsored Research Projects including three Nationally Coordinated Projects. He has advised on more than 125 Consultancy Projects. He has guided 114 M.E. and 10 Ph.D. Theses. He has developed and revised a number of Indian Roads Congress (IRC) Standards, Specifications \& Guidelines. Dr. Jain is Member, Science \& Technology Advisory Council (STAC), Ministry of Shipping, Road Transport \& Highways and Member, PAC of Science \& Engineering Research Council of DST, Govt. of India. Prof. Jain is the recipient of 40 Medals/Prizes/Awards. Prof. Jain was the founder Head of Excellence in Transportation Systems (CTRANS), IIT Roorkee from November 2005 to December 2011.

Dr. Parida graduated in Civil Engineering and Post-Graduated in Urban Planning from School of Planning \& Architecture, New Delhi, took his Ph.D. from University of Roorkee now Indian Institute of Technology Roorkee. He joined Indian Institute of Technology Roorkee in 1996 and became Professor in 2007. His areas of research specialization include Pavement Management System, Transportation Modelling \& Urban Transport Planning. He is a Fellow of The Institution of Engineers (India) \& fellow of Institute of Town Planners, India and Life Member of various other professional institutions in India. Presently, Dr. Parida is Member of IMRA Committee of Indian Roads Congress (IRC). Dr. Parida has contributed over 285 research papers/articles in Indian and Foreign 
Journals and Conference Proceedings. He has published chapters in Two Books. He has also completed 11 sponsored Research Projects and over 300 Consultancy Projects. He has guided more than 70 M.Tech. and eight Ph.D. Theses. Dr. Parida is the recipient of 11 Medals/Prizes/Awards which includes Khosla Research Prizes and Medals, Indian Roads Congress Medals \& Prizes, Recipient of Jawahar Lal Nehru Birth Centenary Award in 2004 of IRC, Medals and Prizes of IE (India).

Received February 2013

Accepted April 2013

Final acceptance in revised form May 2013 